\title{
Evaluation of grain characteristics of domestic wheat (Triticum aestivum L.) obsolete cultivars and landraces
}

\author{
Danijela Kondić, ${ }^{1}$ Sanja Oručević Žuljević, ${ }^{2}$ Đurađ Hajder, ${ }^{1}$ Enez Selimbegović3 \\ ${ }^{1}$ Faculty of Agriculture, University of Banja Luka, Republic of Srpska, Bosnia and Herzegovina; \\ ${ }^{2}$ Faculty of Agricultural and Food Sciences, University of Sarajevo, Bosnia and Herzegovina; \\ ${ }^{3}$ Faculty of Biotechnology, University of Bihać, Bosnia and Herzegovina
}

\begin{abstract}
The research on wheat accessions was carried out in order to evaluate their grain characteristics. Experiment was set in the agro-ecological conditions of Banja Luka in two experimental years (2015/16 and 2016/17). Ten obsolete wheat cultivars (Brkulja, Ličanka, Partizanka, Vuka, Talijanka, Šiđanka, Orašanka, Lozničanka, Dokučajevskaja and Nemcitaevskaja) and two landraces (Podrašnica and Previja) were used. Following grain characteristics were evaluated: grain length $(\mathrm{mm})$, grain width $(\mathrm{mm})$, grain thickness $(\mathrm{mm})$, grain volume $\left(\mathrm{mm}^{3}\right)$, grain surface area $\left(\mathrm{mm}^{2}\right)$, thousand grain weight $(\mathrm{g})$ and grain protein content $(\%)$. Significant interactions were found for most of these traits. The relationship between traits was established by correlation analysis. In this study genotypes Brkulja and Šiđanka showed promising for most of the grain characteristics, while Vuka and Partizanka obtained the highest grain protein content.
\end{abstract}

Correspondence: Danijela Kondić, University of Banja Luka, Faculty of Agriculture, Univerzitetski grad, Bulevar vojvode Petra Bojovića 1A, 78000 Banja Luka, Republic of Srpska, Bosnia and Herzegovina. Tel.: +38751330953 .

E-mail: danijela.kondic@agro.unibl.org

Key words: Genetic resources; grain morphology; grain protein; interaction.

Acknowledgements: the research was financially supported by Ministry for Scientific and Technological Development, Higher Education and Information Society of the Republic of Srpska, and examined wheat accessions are resources of Gene Bank of the Institute of Genetic Resources, University of Banja Luka. On this occasion, the authors would like to thank everyone.

Contributions: the authors contributed equally.

Conflict of interests: the authors declare no potential conflict of interests.

Received for publication: 16 October 2018.

Revision received: 5 November 2019.

Accepted for publication: 8 November 2019.

(C) Copyright: the Author(s), 2020

Licensee PAGEPress, Italy

Italian Journal of Agronomy 2020; 15:1345

doi:10.4081/ija.2020.1345

This article is distributed under the terms of the Creative Commons Attribution Noncommercial License (by-nc 4.0) which permits any noncommercial use, distribution, and reproduction in any medium, provided the original author(s) and source are credited.

\section{Introduction}

Arable land in Bosnia and Herzegovina (BiH) is about 1 million hectares, and the wheat is present at about 66,000 hectares or about $7 \%$, which is the main reason that we still import this basic cereal (Agency for Statistics of Bosnia and Herzegovina, 2018). In the wheat production areas in $\mathrm{BiH}$ obsolete cultivars were present earlier, and today they are replaced by more productive modern cultivars, while wheat landraces can be found in farms with extensive production conditions. Dotlacil et al. (2010) have found that the mean yield of modern cultivars was $51 \%$ higher than the examined obsolete cultivars and landraces. However, objectives in wheat breeding were improvement of crops and agronomic characteristics, as well as resistance against biotic and abiotic stress, but the most important goal was yield increase. Zeven (1999) claimed that wheat landraces are composed of traditional crop varieties developed through farmers and natural selection, adapted to local environmental conditions and management practices, and were often named after a farm or a locality. Landraces were largely cultivated until the first decades of the twentieth century, being progressively abandoned from the early 1970s and replaced with improved, genetically uniform semi-dwarf cultivars as a consequence of the Green Revolution (Ortiz et al., 2007). Landraces and obsolete cultivars can be considered as a valuable portion of the gene pool (Zou and Yang, 1995) due to their genetic diversity. Therefore, wheat genetic resources of each country should be preserved in gene banks, described, classified and evaluated, due to their potential significance to farmers and breeding programs. This research was performed in order to evaluate domestic winter wheat accessions by a quantification of grain morphological and qualitative traits, as well as their stability in two growing seasons. The question was raised whether the selected wheat genotypes have some valuable properties that make them interesting for reactivation in today's agroecological conditions.

\section{Materials and methods}

Plant material for this study consisted of 12 wheat accessions collected and stored by Gene Bank of the Institute of Genetic Resources, University of Banja Luka. Evaluation of morphological and qualitative traits was performed in two experimental years (2015/16 and 2016/17). Experiment was set in the agro-ecological conditions of Banja Luka (444' $\mathrm{N}$; $17^{\circ} 11^{\prime} \mathrm{E}$, and $164 \mathrm{~m}$ altitude). Study included 10 obsolete wheat cultivars (Brkulja, Ličanka, Partizanka, Vuka, Talijanka, Šiđanka, Orašanka, Lozničanka, Dokučaevskaja and Nemcitaevskaja) and two landraces (Podrašnica and Previja) that are still produced in a relatively poor households, as presented in Table 1 . 
Field experiments were based on a randomized complete block design with four replications, with $1 \times 1 \mathrm{~m}$ plot size. All measurements were performed on 30 grains per replication. Standard production technology for winter wheat was applied, with seeding density of 504 grains $\mathrm{m}^{-2}$. Sowing was performed on the $27^{\text {th }}$ of October in 2015/16 and on the $2^{\text {nd }}$ of November in 2016/17. Wheat harvest in both experimental years was at the end of the first decade of July. Plant samples were taken for the analysis just prior to harvest.

The average temperature in the vegetation period for winter wheat (from October to June) was $10.1^{\circ} \mathrm{C}$ in $2015 / 16$ and $9.1^{\circ} \mathrm{C}$ in $2016 / 17$, while the total precipitation in the same period was 855.8 $\mathrm{mm}$ in $2015 / 16$ and $737.1 \mathrm{~mm}$ in 2016/17 (Table 2).

Dimensions of individual seed were calculated on the basis of following measurements: grain length (GL), grain width $(\mathrm{GW})$ and grain thickness (GT), measured along the three principal axial dimensions by using a digital calliper with $0.01 \mathrm{~mm}$ accuracy (MIB, Germany)

Grain volume (GV) was calculated (Oručević et al., 2016) by using the following formula (Eq. 1):

$\mathrm{GV}\left(\mathrm{mm}^{3}\right)=0.52 \times \mathrm{GL} \times \mathrm{GW} \times \mathrm{GT}$

where 0.52 is a coefficient for wheat and barley seed shape. Grain surface area (GA) was also calculated (Eq. 2):

$\mathrm{GA}\left(m m^{2}\right)=12.56 \times \mathrm{R}(G L+3 R)$

where $\mathrm{R}$ (seed diameter) was calculated as $\mathrm{R}=(5 G L+5 G W) / 60$.

Grain protein content (PC) in \% was calculated by multiplica- tion of percentage of nitrogen content determined by Kjeldahl method with conversion factor for wheat $(\mathrm{N} \times 5.7)$. Grain protein content, as well as the thousand grain weight, were made in three replicates.

A two-factorial analysis of variance was conducted, with genotypes and years as factors. Significant differences were previously detected by calculating $\mathrm{F}$ test statistics with $\mathrm{P}<0.05$ and $\mathrm{P}<0.01$. Multiple comparisons between genotypes, years or genotype $x$ year interactions were performed for significant F-values, by Fisher's post-hoc least significant difference (LSD) test at significance $\mathrm{P}<0.05 \mathrm{P}<0.01$, for different wheat seed characteristics. Relationship between analysed grain characteristics was evaluated by correlation analysis, using Pearson's correlation coefficient, at $\mathrm{P}<0.05$ and $\mathrm{P}<0.01$. All calculations were done in IBM SPSS Statistics 22.0 statistical software.

\section{Results}

\section{Grain length, grain width and grain thickness}

Obtained results (Table 3 ) indicate that the average GL ranged from $6.26 \mathrm{~mm}$ in genotype Podrašnica to $7.29 \mathrm{~mm}$ in genotype Brkulja in 2015/16 and from $5.70 \mathrm{~mm}$ in genotype Dokučaevskaja to $6.76 \mathrm{~mm}$ in genotype Brkulja in 2016/17. According to the analysis of variance the effects of genotype and year were both statistically significant at $\mathrm{P}<0.001$. However, the interaction effect genotype $\times$ year was significant at $\mathrm{P}<0.05$, therefore further analysis will be based on 24 genotype $\times$ year interaction means. According to the LSD-test, the highest GL of $7.29 \mathrm{~mm}$ in Brkulja

Table 1. General characteristics of analysed winter wheat genotypes.

\begin{tabular}{|c|c|c|c|c|}
\hline & $\begin{array}{c}\text { Genotype } \\
\text { name }\end{array}$ & $\begin{array}{c}\text { Genotype } \\
\text { status }\end{array}$ & Genotype origin & ssion number \\
\hline 1. & Podrašnica & $\mathrm{L}$ & Mrkonjić Grad, Bosnia and Herzegovina & GB01054 \\
\hline 2. & Brkulja & $\mathrm{OC}$ & Faculty of Agriculture and Institute for Agricultural Research Novi Sad, Serbia (YBP) & GB00107 \\
\hline 3. & Dokučaevskaja & $\mathrm{OC}$ & Krasnodar Research Institute of Agriculture PP Lukyanenko, Russia & GB00213 \\
\hline 4. & Ličanka & $\mathrm{OC}$ & Institute for Agricultural Research Novi Sad, Serbia (YBP) & GB00171 \\
\hline 5. & Partizanka & $\mathrm{OC}$ & Institute for Agricultural Research Novi Sad, Serbia (YBP) & GB00089 \\
\hline 6. & Vuka & $\mathrm{OC}$ & Institute for Plant Breeding and Plant Production Zagreb, Croatia (YBP) & GB00105 \\
\hline 7. & Talijanka & $\mathrm{OC}$ & Obsolete cultivar from Italy (original name unknown) & GB00849 \\
\hline 8. & Previja & L & Ribnik, Bosnia and Herzegovina & GB01060 \\
\hline 9. & Nemcitaevskaja & $\mathrm{OC}$ & Obsolete cultivar from the Soviet Union & GB00193 \\
\hline 10. & Šiđanka & $\mathrm{OC}$ & Institute for Agricultural Research Novi Sad, Serbia (YBP) & GB00146 \\
\hline 11. & Orašanka & $\mathrm{OC}$ & Centre for Small Grains in Kragujevac, Serbia (YBP) & GB00208 \\
\hline 12. & Lozničanka & $\mathrm{OC}$ & Centre for Small Grains in Kragujevac and Institute for Agricultural Research Novi Sad, Serbia (YBP) & GB00831 \\
\hline
\end{tabular}

L, landrace; OC, obsolete cultivar; YBP, Yugoslav breeding program.

Table 2. The average monthly air temperatures $\left({ }^{\circ} \mathrm{C}\right)$ and total monthly precipitation $(\mathrm{mm})$ for the area of Banja Luka.

\begin{tabular}{|c|c|c|c|c|c|c|c|c|c|c|c|c|c|}
\hline Year & & I & II & III & IV & V & VI & VII & VIII & IX & $\mathrm{X}$ & XI & XII \\
\hline 2015 & $\begin{array}{c}{ }^{\circ} \mathrm{C} \\
\mathrm{mm}\end{array}$ & $\begin{array}{c}3.4 \\
111.2\end{array}$ & $\begin{array}{c}2.4 \\
91.1\end{array}$ & $\begin{array}{c}7.3 \\
79.0\end{array}$ & $\begin{array}{l}11.8 \\
54.1\end{array}$ & $\begin{array}{c}17.4 \\
117.6\end{array}$ & $\begin{array}{l}20.9 \\
60.5\end{array}$ & $\begin{array}{l}25.2 \\
20.5\end{array}$ & $\begin{array}{l}24.0 \\
22.8\end{array}$ & $\begin{array}{l}18.3 \\
75.0\end{array}$ & $\begin{array}{c}11.5 \\
142.7\end{array}$ & $\begin{array}{c}7.1 \\
85.7\end{array}$ & $\begin{array}{l}3.2 \\
8.1\end{array}$ \\
\hline 2016 & $\begin{array}{c}{ }^{\circ} \mathrm{C} \\
\mathrm{mm}\end{array}$ & $\begin{array}{c}2.3 \\
109.7\end{array}$ & $\begin{array}{c}7.6 \\
108.5\end{array}$ & $\begin{array}{c}8.0 \\
112.2\end{array}$ & $\begin{array}{l}13.5 \\
70.5\end{array}$ & $\begin{array}{c}16.2 \\
100.6\end{array}$ & $\begin{array}{c}21.5 \\
117.8\end{array}$ & $\begin{array}{c}23.3 \\
125.9\end{array}$ & $\begin{array}{c}20.5 \\
100.2\end{array}$ & $\begin{array}{l}17.8 \\
63.3\end{array}$ & $\begin{array}{l}10.6 \\
76.0\end{array}$ & $\begin{array}{c}7.4 \\
68.9\end{array}$ & $\begin{array}{l}0.4 \\
5.0\end{array}$ \\
\hline 2017 & $\begin{array}{c}{ }^{\circ} \mathrm{C} \\
\mathrm{mm}\end{array}$ & $\begin{array}{r}-3.6 \\
87.2 \\
\end{array}$ & $\begin{array}{c}5.5 \\
100.4 \\
\end{array}$ & $\begin{array}{c}9.7 \\
124.0 \\
\end{array}$ & $\begin{array}{c}11.8 \\
148.4 \\
\end{array}$ & $\begin{array}{l}17.5 \\
92.1 \\
\end{array}$ & $\begin{array}{l}22.9 \\
35.1 \\
\end{array}$ & $\begin{array}{l}24.4 \\
38.0 \\
\end{array}$ & $\begin{array}{l}24.0 \\
42.5 \\
\end{array}$ & $\begin{array}{c}15.7 \\
134.4 \\
\end{array}$ & $\begin{array}{l}11.9 \\
99.3 \\
\end{array}$ & $\begin{array}{c}6.9 \\
106.3 \\
\end{array}$ & $\begin{array}{c}4.6 \\
142.1 \\
\end{array}$ \\
\hline
\end{tabular}


in $2015 / 16$ was not statistically different from GL in Šiđanka in $2015 / 16(7.08 \mathrm{~mm})$, but was statistically significantly higher at $\mathrm{P}<0.01$ in comparison to remaining genotype $\times$ year combinations.

The average GW ranged from $3.15 \mathrm{~mm}$ (Podrašnica) to 3.66 $\mathrm{mm}$ (Šiđanka) in 2015/16 and from $2.66 \mathrm{~mm}$ (Dokučaevskaja) to $3.08 \mathrm{~mm}$ (Šiđanka) in 2016/17. The effects of genotype and year were both statistically significant at $\mathrm{P}<0.001$. The interaction effect was significant at $\mathrm{P}<0.01$. LSD-test showed that the GW in Šiđanka in 2015/16 (3.66 mm) was statistically significantly higher at $\mathrm{P}<0.01$ in comparison to remaining combinations. The average GT ranged from $2.57 \mathrm{~mm}$ (Dokučaevskaja) to $3.05 \mathrm{~mm}$ (Brkulja) in $2015 / 16$ and from $2.08 \mathrm{~mm}$ (Nemcitaevskaja) to $2.32 \mathrm{~mm}$ (Šiđanka) in 2016/17. The effects of genotype and year were both statistically significant at $\mathrm{P}<0.001$. The interaction effect was significant at $\mathrm{P}<0.001$. According to the LSD-test, GT in Brkulja in $2015 / 16$ (3.05 mm) was statistically significantly higher at $\mathrm{P}<0.01$ in comparison to remaining combinations.

According to Figure 1 all genotypes showed decrease in the average GL in 2016/17. This decrease was less noticeable in Orašanka and Podrašnica, which expressed stability of GL during experiment. The largest decrease of GL was present in Dokučaevskaja in 2016/17.

The average GW and GT had similar tendency, with Brkulja and Šiđanka showing larger values among all tested genotypes, which is the reason why they can be marked out as genotypes with the largest grains in both seasons.

\section{Grain volume and grain surface area}

According to the results (Table 4) the average GV ranged from $27.27 \mathrm{~mm}^{3}$ (Dokučaevskaja) to $39.73 \mathrm{~mm}^{3}$ (Brkulja) in 2015/16 and from $16.77 \mathrm{~mm}^{3}$ (Dokučaevskaja) to $24.38 \mathrm{~mm}^{3}$ (Šiđanka) in $2016 / 17$. The effects of genotype and year were both statistically significant at $\mathrm{P}<0.001$. The interaction effect genotype $\times$ year was significant at $\mathrm{P}<0.01$. According to the LSD-test, the highest $\mathrm{GV}$ of $39.73 \mathrm{~mm}^{3}$ in Brkulja in 2015/16 was not statistically different from GV in Šiđanka in 2015/16 (38.67 mm), but was statistically significantly higher at $\mathrm{P}<0.01$ in comparison to remaining genotype $\times$ year combinations.

The average GA ranged from $47.31 \mathrm{~mm}^{2}$ (Dokučaevskaja) to $60.50 \mathrm{~mm}^{2}$ in (Brkulja) in 2015/16 and from $34.57 \mathrm{~mm}^{2}$ (Dokučaevskaja) to $44.94 \mathrm{~mm}^{2}$ (Brkulja) in 2016/17. The effects of genotype and year were both statistically significant at $\mathrm{P}<0.001$. The interaction effect was not statistically significant, therefore the analysis was done within genotype and year main effects, and did not need a graphical representation. According to the LSD-test, the highest GA of $60.50 \mathrm{~mm}^{2}$ in Brkulja was not statistically different from GA in Šiđanka $\left(59.53 \mathrm{~mm}^{2}\right)$, but was statistically significantly higher at $\mathrm{P}<0.01$ in comparison to remaining genotypes. The average GA in $2015 / 16\left(53.50 \mathrm{~mm}^{2}\right)$ was statistically significantly higher at $\mathrm{P}<0.01$ in comparison to average GA in $2016 / 17\left(40.17 \mathrm{~mm}^{2}\right)$.

According to Figure 1, in all genotypes GV decreased in 2016/17. The highest GV in Brkulja and Šiđanka in both experimental years was noticeable, which distinguishes them from other genotypes, as confirmed by LSD-test. When it comes to GA, based on the LSD-test, Brkulja and Šiđanka showed larger values among tested genotypes, with significantly higher values in 2015/16.

\section{Thousand grain weight}

The average thousand grain weight (TGW) ranged from 18.80 $\mathrm{g}$ (Dokučaevskaja) to $27.96 \mathrm{~g}$ (Brkulja) in 2015/16 and from 22.37 $\mathrm{g}$ (Dokučaevskaja) to $37.53 \mathrm{~g}$ (Brkulja) in 2016/17. The effects of genotype and year were both statistically significant at $\mathrm{P}<0.001$. The interaction effect was significant at $\mathrm{P}<0.05$. According to the LSD-test, the highest TGW of $37.53 \mathrm{~g}$ in Brkulja in 2016/17 was statistically significantly higher at $\mathrm{P}<0.01$ in comparison to all other combinations (interaction means).

Table 3. Grain length $(\mathrm{mm})$, grain width $(\mathrm{mm})$ and grain thickness $(\mathrm{mm})$ of 12 wheat genotypes.

\begin{tabular}{|c|c|c|c|c|c|c|}
\hline \multirow[t]{2}{*}{ Genotypes/Trait } & \multicolumn{2}{|c|}{ GL } & \multicolumn{2}{|c|}{ GW } & \multicolumn{2}{|c|}{ GT } \\
\hline & $\begin{array}{c}2015 / 16 \\
\overline{\mathrm{X}} \pm S_{\bar{x}} C_{v}\end{array}$ & $\begin{array}{l}2016 / 17 \\
\bar{X} \pm S_{\bar{x}} C_{v}\end{array}$ & $\begin{array}{l}2015 / 16 \\
\overline{\mathrm{X}} \pm S_{\bar{x}} C_{v}\end{array}$ & $\begin{array}{l}2016 / 17 \\
\bar{X} \pm S_{\bar{x}} C_{v}\end{array}$ & $\begin{array}{l}2015 / 16 \\
\overline{\mathrm{X}} \pm S_{\bar{x}} C_{v}\end{array}$ & $\begin{array}{l}2016 / 17 \\
\bar{X} \pm S_{\bar{x}} C_{v}\end{array}$ \\
\hline Podrašnica & $6.26 \pm 0.05910 .48$ & $6.16 \pm 0.0457 .95$ & $3.15 \pm 0.0279 .67$ & $2.70 \pm 0.02811 .33$ & $2.76 \pm 0.02811 .12$ & $2.11 \pm 0.02010 .48$ \\
\hline Brkulja & $7.29 \pm 0.0446 .64$ & $6.76 \pm 0.0538 .66$ & $3.44 \pm 0.0196 .17$ & $3.07 \pm 0.0269 .33$ & $3.05 \pm 0.0228 .07$ & $2.23 \pm 0.02110 .18$ \\
\hline Dokučaevskaja & $6.45 \pm 0.0427 .19$ & $5.70 \pm 0.0407 .75$ & $3.17 \pm 0.0258 .79$ & $2.66 \pm 0.02610 .57$ & $2.57 \pm 0.0187 .62$ & $2.12 \pm 0.0189 .50$ \\
\hline Ličanka & $6.69 \pm 0.0447 .17$ & $6.26 \pm 0.0437 .46$ & $3.43 \pm 0.0247 .82$ & $2.93 \pm 0.0269 .87$ & $2.86 \pm 0.0217 .99$ & $2.23 \pm 0.02411 .97$ \\
\hline Partizanka & $6.79 \pm 0.0416 .54$ & $6.45 \pm 0.0447 .45$ & $3.37 \pm 0.0216 .71$ & $3.03 \pm 0.03512 .62$ & $2.84 \pm 0.0197 .29$ & $2.20 \pm 0.02612 .92$ \\
\hline Vuka & $6.33 \pm 0.0447 .56$ & $5.89 \pm 0.06211 .71$ & $3.22 \pm 0.0227 .34$ & $2.78 \pm 0.02911 .27$ & $2.76 \pm 0.0197 .70$ & $2.24 \pm 0.02612 .99$ \\
\hline Talijanka & $6.57 \pm 0.0477 .87$ & $6.24 \pm 0.0569 .88$ & $3.41 \pm 0.0289 .13$ & $2.82 \pm 0.03011 .56$ & $2.86 \pm 0.0238 .83$ & $2.22 \pm 0.02412 .09$ \\
\hline Previja & $6.89 \pm 0.0437 .07$ & $6.41 \pm 0.0539 .03$ & $3.44 \pm 0.0216 .63$ & $2.88 \pm 0.02810 .67$ & $2.90 \pm 0.0176 .48$ & $2.19 \pm 0.01910 .12$ \\
\hline Nemcitaevskaja & $6.44 \pm 0.0457 .60$ & $6.21 \pm 0.0458 .10$ & $3.37 \pm 0.0237 .59$ & $2.77 \pm 0.02610 .29$ & $2.83 \pm 0.0207 .79$ & $2.08 \pm 0.02010 .83$ \\
\hline Šiđanka & $7.08 \pm 0.0467 .13$ & $6.58 \pm 0.0518 .62$ & $3.66 \pm 0.0257 .34$ & $3.08 \pm 0.02910 .48$ & $2.87 \pm 0.0187 .22$ & $2.32 \pm 0.02913 .79$ \\
\hline Orašanka & $6.67 \pm 0.0457 .54$ & $6.59 \pm 0.0447 .25$ & $3.30 \pm 0.0206 .66$ & $2.84 \pm 0.0249 .29$ & $2.93 \pm 0.0186 .77$ & $2.18 \pm 0.0199 .61$ \\
\hline Lozničanka & $6.94 \pm 0.0426 .72$ & $6.49 \pm 0.0386 .41$ & $3.30 \pm 0.0206 .55$ & $2.85 \pm 0.02610 .11$ & $2.77 \pm 0.0187 .22$ & $2.15 \pm 0.02211 .32$ \\
\hline $\mathrm{F}_{\text {genotype }}$ & \multicolumn{2}{|c|}{$23.72 * * *$} & \multicolumn{2}{|c|}{$23.48 * * *$} & \multicolumn{2}{|c|}{$13.42 * * *$} \\
\hline $\mathrm{F}_{\text {year }}$ & \multicolumn{2}{|c|}{$125.03^{* * *}$} & \multicolumn{2}{|c|}{$982.00^{* * *}$} & \multicolumn{2}{|c|}{$2668.62^{* * *}$} \\
\hline $\mathrm{Fg}_{\text {enotype } \times \text { year }}$ & \multicolumn{2}{|c|}{$2.43^{*}$} & \multicolumn{2}{|c|}{$2.58 * *$} & \multicolumn{2}{|c|}{$5.90^{* * *}$} \\
\hline $\mathrm{LSD}_{0.05}$ & \multicolumn{2}{|c|}{0.2391} & \multicolumn{2}{|c|}{0.1075} & \multicolumn{2}{|c|}{0.0860} \\
\hline $\mathrm{LSD}_{0.01}$ & \multicolumn{2}{|c|}{0.3173} & \multicolumn{2}{|c|}{0.1427} & \multicolumn{2}{|c|}{0.1142} \\
\hline
\end{tabular}

GL, grain length (mm); GW, grain width (mm); GT, grain thickness (height) (mm). *Significant at $\mathrm{P}<0.05 ;{ }^{* *}$ significant at $\mathrm{P}<0.01$; *** significant at $\mathrm{P}<0.001$. 
As opposed to other grain characteristics, the average TGW obtained an increase in 2016/17 (Figure 1). Brkulja had the highest values of TGW in both experimental years, followed by Previja and Šiđanka.

\section{Grain protein content}

The average PC ranged from $10.06 \%$ (Nemcitaevskaja) to $12.76 \%$ (Vuka) in 2015/16 and from $10.73 \%$ (Lozničanka) to $13.43 \%$ (Partizanka) in 2016/17 (Table 4). The effects of genotype and year were both statistically significant at $\mathrm{P}<0.001$. The interaction effect was also significant at $\mathrm{P}<0.001$. Performed LSD-test showed that there were no statistically significant difference between PC in Partizanka in 2016/17 (13.43 \%) and PC in Brkulja in 2016/17 (12.86 \%). Obtained PC in Vuka in 2015/16 (12.76 \%) was statistically significantly lower at $\mathrm{P}<0.05$ in comparison to Partizanka in 2016/17, while the remaining combinations obtained statistically significantly lower $\mathrm{PC}$ at $\mathrm{P}<0.01$ in comparison to Partizanka in 2016/17.

According to Figure 1 genotypes reacted very differently considering PC in two seasons. Šiđanka expressed stability in PC during experiment, Vuka, Orašanka and Lozničanka obtained a decrease of PC in the 2016/17, while remaining genotypes
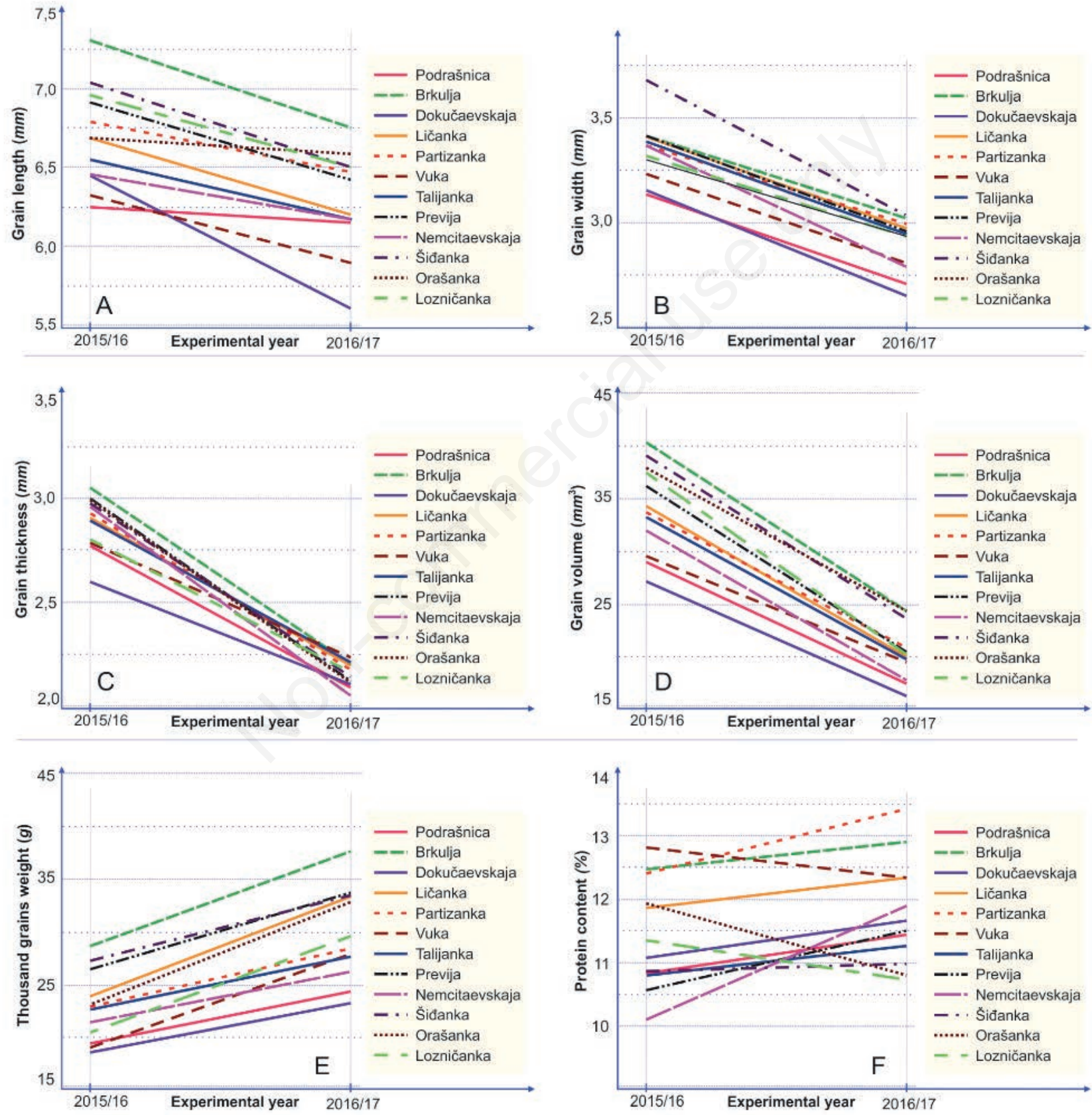

Figure 1. The analysis of interaction effects genotype $\times$ year. A) grain length; B) grain width; C) grain thickness; D) grain volume; E) thousand grain weight; F) grain protein content $(\%)$. 
obtained an increase. Partizanka and Brkulja, due to their increase, as well as the highest PC can be marked out as the most promising genotypes.

\section{Relationships between analysed grain characteristics}

According to Table 5, all correlations were positive. There were no significant correlations between PC (\%) and remaining traits. GL correlated significantly (at $\mathrm{P}<0.01$ ) with $\mathrm{GW}$ and GT while remaining correlations were highly significant (at $\mathrm{P}<0.001$ ).

\section{Discussion}

The analyses of genetic diversity are very important in different breeding programs and management of plant genetic resources. Grain size and shape are two among main targets in wheat breed- ing programs (Gegas et al., 2010; Okamoto et al., 2013). Also, milling properties of wheat depend on the mechanical properties of the kernels, which are dependent on kernel size (Dziki and Laskowski, 2004). Grain morphology depends on accumulation of dry matter and water. The first dimension that reaches its maximum value is grain length, which happens about 15 days after anthesis, followed by grain width, height and volume (Hasan et al., 2011). Grain dimensions then slightly decrease and reach their final size at maturity (Liziana et al., 2010). In addition, the grain size is under a complex genetic control and at the same time is influenced by the environment (Cristina et al., 2016).

The average GL in our research was $6.70 \mathrm{~mm}$ in 2015/16 and $6.31 \mathrm{~mm}$ in $2016 / 17$. This is similar to results by Varga et al. (2003) obtained on modern Croatian wheat cultivars and Xie et al. (2015). The average GW was $3.35 \mathrm{~mm}$ in $2015 / 16$ and $2.87 \mathrm{~mm}$ in 2016/17, is in accordance with Gegas et al. (2010) and Abdipour et al. (2016) who studied 98 Iranian bread wheat landraces. The aver-

Table 4. Grain volume $\left(\mathrm{mm}^{3}\right)$, grain surface area $\left(\mathrm{mm}^{2}\right)$, thousand grain weight $(\mathrm{g})$ and grain protein content $(\%)$ of 12 wheat genotypes.

\begin{tabular}{|c|c|c|c|c|c|c|c|c|}
\hline \multirow{2}{*}{$\begin{array}{l}\text { Genotypes/ } \\
\text { Trait }\end{array}$} & \multicolumn{2}{|c|}{ GV } & \multicolumn{2}{|c|}{ GA } & \multicolumn{2}{|c|}{ TGW } & \multicolumn{2}{|c|}{ PC } \\
\hline & $\begin{array}{l}2015 / 16 \\
\bar{X} \pm S_{\bar{x}} C_{v}\end{array}$ & $\begin{array}{l}2016 / 17 \\
\bar{X} \pm S_{\bar{x}} C_{v}\end{array}$ & $\begin{array}{l}2015 / 16 \\
\bar{X} \pm S_{\bar{x}} C_{v}\end{array}$ & $\begin{array}{l}2016 / 17 \\
\bar{X} \pm S_{\bar{x}} C_{v}\end{array}$ & $\begin{array}{l}2015 / 16 \\
\bar{X} \pm S_{\bar{x}} C_{v}\end{array}$ & $\begin{array}{l}2016 / 17 \\
\bar{X} \pm S_{\bar{x}} C_{v}\end{array}$ & $\begin{array}{l}2015 / 16 \\
\mathrm{X} \pm S_{x} C_{v}\end{array}$ & $\begin{array}{l}2016 / 17 \\
\mathrm{X} \pm S_{x} C_{v}\end{array}$ \\
\hline Podrašnica & $28.30 \pm 0.4818 .47$ & $18.29 \pm 0.3219 .22$ & $47.92 \pm 0.5412 .38$ & $37.11 \pm 0.4312 .62$ & $19.51 \pm 0.948 .32$ & $23.78 \pm 1.7712 .91$ & $10.83 \pm 0.477 .56$ & $11.44 \pm 1.0415 .73$ \\
\hline Brkulja & $39.73 \pm 0.461281$ & $24.14 \pm 0.4218 .68$ & $60.50 \pm 0.478 .50$ & $44.94 \pm 0.5112 .36$ & $27.96 \pm 1.7110 .57$ & $37.53 \pm 4.0218 .56$ & $12.47 \pm 0.8111 .22$ & $12.86 \pm 0.7510 .07$ \\
\hline \multicolumn{2}{|c|}{ Dokučaevskaja27.27 $\pm 0.4015 .99$} & $16.77 \pm 0.2516 .61$ & $47.31 \pm 0.4610 .56$ & $34.57 \pm 0.3511 .11$ & $18.80 \pm 0.787 .22$ & $22.37 \pm 1.3410 .34$ & $11.04 \pm 0.619 .62$ & $11.60 \pm 0.7310 .88$ \\
\hline Ličanka & $34.12 \pm 0.5116 .25$ & $21.35 \pm 0.3920 .08$ & $54.38 \pm 0.5410 .76$ & $40.87 \pm 0.4812 .84$ & $24.38 \pm 1.097 .78$ & $33.55 \pm 1.688 .67$ & $11.85 \pm 0.639 .14$ & $12.27 \pm 0.446 .20$ \\
\hline Partizanka & $33.78 \pm 0.4213 .73$ & $22.40 \pm 0.4923 .75$ & $54.21 \pm 0.469 .29$ & $42.49 \pm 0.5815 .02$ & $23.63 \pm 1.8613 .67$ & $28.36 \pm 1.046 .35$ & $12.32 \pm 0.567 .88$ & $13.43 \pm 0.9612 .43$ \\
\hline Vuka & $29.32 \pm 0.4115 .44$ & $19.09 \pm 0.4726 .91$ & $49.04 \pm 0.4710 .49$ & $37.54 \pm 0.6017 .43$ & $19.98 \pm 1.3111 .33$ & $27.51 \pm 1.469 .18$ & $12.76 \pm 0.7510 .12$ & $12.38 \pm 0.648 .93$ \\
\hline Talijanka & $33.42 \pm 0.5417 .52$ & $20.25 \pm 0.4021 .71$ & $53.49 \pm 0.5711 .67$ & $39.51 \pm 0.5214 .26$ & $23.53 \pm 1.289 .42$ & $27.91 \pm 2.1513 .36$ & $10.82 \pm 0.426 .67$ & $11.26 \pm 0.528 .03$ \\
\hline Previja & $35.76 \pm 0.4313 .38$ & $20.99 \pm 0.3819 .78$ & $56.25 \pm 0.479 .25$ & $40.71 \pm 0.4913 .18$ & $25.88 \pm 1.469 .76$ & $33.94 \pm 3.3817 .23$ & $10.61 \pm 0.508 .18$ & $11.50 \pm 0.456 .70$ \\
\hline \multicolumn{3}{|c|}{ Nemcitaevskaja31.92 $\pm 0.4415 .0118 .63 \pm 0.3420 .20$} & $51.82 \pm 0.4810 .10$ & $37.71 \pm 0.4513 .14$ & $21.56 \pm 0.826 .55$ & $26.83 \pm 1.469 .43$ & $10.06 \pm 0.467 .93$ & $11.87 \pm 0.8011 .67$ \\
\hline Šiđanka & $38.67 \pm 0.5415 .25$ & $24.38 \pm 0.4821 .64$ & $59.53 \pm 0.5710 .54$ & $44.71 \pm 0.5613 .72$ & $26.35 \pm 1.077 .03$ & $33.88 \pm 3.0915 .81$ & $10.85 \pm 0.579 .10$ & $10.91 \pm 0.6911 .03$ \\
\hline Orašanka & $33.61 \pm 0.4313 .99$ & $21.29 \pm 0.3618 .61$ & $53.72 \pm 0.479 .57$ & $41.30 \pm 0.4612 .05$ & $23.43 \pm 1.6412 .09$ & $33.10 \pm 3.0515 .96$ & $11.87 \pm 0.659 .52$ & $10.84 \pm 0.467 .33$ \\
\hline Lozničanka & $33.06 \pm 0.4013 .35$ & $20.77 \pm 0.3317 .46$ & $53.81 \pm 0.448 .93$ & $40.61 \pm 0.4010 .88$ & $21.95 \pm 2.0115 .83$ & $29.44 \pm 3.0718 .05$ & $11.30 \pm 0.7511 .43$ & $10.73 \pm 0.579 .13$ \\
\hline $\mathrm{F}_{\text {genotype }}$ & \multicolumn{2}{|c|}{$35.47 * * *$} & \multicolumn{2}{|c|}{$35.44^{* * *}$} & \multicolumn{2}{|c|}{$61.41^{* * *}$} & \multicolumn{2}{|c|}{$16.66^{* * *}$} \\
\hline $\mathrm{F}_{\text {year }}$ & \multicolumn{2}{|c|}{$1882.62^{* * *}$} & \multicolumn{2}{|c|}{$1492.80^{* * *}$} & \multicolumn{2}{|c|}{$637.30^{* * *}$} & \multicolumn{2}{|c|}{$12.24^{* * *}$} \\
\hline $\mathrm{F}_{\text {genotype }} \times$ yea & \multicolumn{2}{|c|}{$3.23^{* *}$} & \multicolumn{2}{|c|}{$1.70 \mathrm{~ns}$} & \multicolumn{2}{|c|}{$5.69 *$} & \multicolumn{2}{|c|}{$4.16^{* * *}$} \\
\hline $\mathrm{LSD}_{0.05}$ & \multicolumn{2}{|c|}{1.9975} & \multicolumn{2}{|c|}{$\begin{array}{l}\mathrm{LSD}_{\mathrm{GENOTYPE}}=1.6842 \\
\mathrm{LSD}_{\text {YEAR }}=0.6876\end{array}$} & \multicolumn{2}{|c|}{1.8521} & \multicolumn{2}{|c|}{0.6419} \\
\hline $\mathrm{LSD}_{0.01}$ & \multicolumn{2}{|c|}{2.6513} & \multicolumn{2}{|c|}{$\begin{array}{c}\mathrm{LSD}_{\mathrm{GENOTYPE}}=2.2354 \\
\mathrm{LSD}_{\mathrm{YEAR}}=0.9126\end{array}$} & \multicolumn{2}{|c|}{2.4582} & \multicolumn{2}{|c|}{0.8563} \\
\hline
\end{tabular}

GV, grain volume $\left(\mathrm{mm}^{3}\right)$; GA, grain surface area $\left(\mathrm{mm}^{2}\right)$; TGW, thousand grain weight $(\mathrm{g}) ; \mathrm{PC}$, grain protein content (\%); ns, statistically not significant. *Significant at $\mathrm{P}<0.05 ; * *$ significant at $\mathrm{P}<0.01$; *** significant at $\mathrm{P}<0.001$.

Table 5. Pearson's correlation coefficients between different traits (two year-average).

\begin{tabular}{lcccccc} 
Variable & GL & GW & GT & GV & GA & TGW \\
GW & $0.8290^{* *}$ & 1 & & & & \\
GT & $0.7894^{* *}$ & $0.8344^{* * *}$ & 1 & & & \\
GV & $0.9405^{* * *}$ & $0.9524^{* * *}$ & $0.9111^{* * *}$ & 1 & & \\
GA & $0.9553^{* * *}$ & $0.9457^{* * *}$ & $0.8977^{* * *}$ & $0.9987^{* * *}$ & 1 & 1 \\
\hline TGW & $0.8862^{* * *}$ & $0.8608^{* * *}$ & $0.9254^{* * *}$ & $0.9471^{* * *}$ & $0.9419^{* * *}$ & $0.1946^{\mathrm{ns}}$ \\
PC & $0.1075^{\mathrm{ns}}$ & $0.1649^{\mathrm{ns}}$ & $0.2995^{\mathrm{ns}}$ & $0.1826^{\mathrm{ns}}$ & $0.1768^{\mathrm{ns}}$ & 1 \\
\hline
\end{tabular}

GL, grain length (mm); GW, grain width (mm); GT, grain thickness (height) (mm); GV, grain volume ( $\left.\mathrm{mm}^{3}\right)$; GA, grain surface area (mm²); TGW, thousand grain weight (g); PC, grain protein content (\%); ns, statistically not significant. *Significant at $\mathrm{P}<0.05$; ** significant at $\mathrm{P}<0.01$; ${ }^{* * *}$ significant at $\mathrm{P}<0.001$. 
age GT was $2.83 \mathrm{~mm}$ in 2015/16 and $2.19 \mathrm{~mm}$ in 2016/17, similar to Xie et al. (2015).

Grain characteristics, such as grain volume, perimeter and area due to their larger heritability than grain yield, can be used as indirect indices in grain yield improvement (Abdipour et al., 2016). The average GV in our research was $33.25 \mathrm{~mm}$ in $2015 / 16$ and 20.70 in 2016/17. These results are in accordance with Nielsen et al. (2003) and Grabowski et al. (2012) who studied different wheat cultivars. The average GA was $53.50 \mathrm{~mm}^{2}$ in $2015 / 16$ and 40.17 $\mathrm{mm}^{2}$ in 2016/17. Other researchers reported relatively less GA. In Abdipour et al. (2016) GA ranged from 8.1 to $26.5 \mathrm{~mm}^{2}$ and in Gegas et al. (2010) from 14.69 to $33.08 \mathrm{~mm}^{2}$ in different wheat genotypes. GA ranging from 11.44 to $24.71 \mathrm{~mm}^{2}$ (Okamoto et al., 2013) and from 8.32 to $14.93 \mathrm{~mm}^{2}$ (Yan et al., 2017) was previously obtained.

Calculated TGW, marked as one of the main grain size variables (Gegas et al., 2010), is also one of the main target of wheat breeding activities (Abdipour et al., 2016). The average TGW in our research was 23.08 g in 2015/16 and 29.85 g in 2016/17, similar to Yan et al. (2017). According to scale of characterization and evaluation descriptors of European Wheat Database, obtained TGW value of examined wheat genotypes belong to the category of very low to intermediate. However, TGW can be very variable trait, i.e. in bread wheat landraces it can range from 39.0 to $56.6 \mathrm{~g}$ (Piergiovanni, 2013) and from 26.2 to $68.7 \mathrm{~g}$ (Abdipour et al., 2016). TGW of 55 Bulgarian wheat accessions was $40.59 \mathrm{~g}$ (Desheva, 2014). In Dotlacil et al. (2003) TGW ranged from 36.3 to $41.7 \mathrm{~g}$ in winter wheat landraces, obsolete cultivars and modern cultivars from different countries of origin.

In our study genotypes Brkulja and Šiđanka showed some promising characteristics regarding grain characteristics. In the 2015/16 Brkulja obtained the highest GL, GT, GV, GA and TGW, and Šiđanka had similar results, with the highest GW. In 2016/17 Brkulja achieved the highest GL, GA and TGW, similar to Šiđanka achieving the highest value for GT and GV.

It is well known that the economic value of wheat depends on the grain morphological and chemical characteristics. Grain protein content is important component of wheat grain quality due to its effect on milling yield, end-use quality and market price (Abdipour et al., 2016). Wheat grain storage protein content and composition are main determinants of the end-use value of bread wheat grain (Plessis et al., 2013). Baking potential of wheat flour is influenced by many factors, most notably protein content (Huebner et al., 1999). According to Shevry (2009) grain wheat in the dry matter contains about 8 to $15 \%$ proteins. The average PC in our research was $11.39 \%$ in $2015 / 16$ and $11.76 \%$ in 2017 , with genotypes Partizanka and Vuka as dominant ones. However, according to the scale of IPGRI descriptor 6.3 .3 (protein content) we must note that highest obtained protein content $(13.43 \%)$ in genotypes Partizanka correspond to intermediate values. In Dotlacil et al. (2003) PC ranged from 13.2 to $13.3 \%$ in modern cultivars and from 15.3 to $16.2 \%$ in landraces and obsolete cultivars. In Punia et al. (2017) PC ranged from 9.03 to $12.33 \%$ in different cultivars.

Based on the average temperatures and total precipitation (Table 2) in the vegetation period for winter wheat (from October to June) it is indicative that $2015 / 16$ season was $1^{\circ} \mathrm{C}$ warmer than $2016 / 17$ and $2.3^{\circ} \mathrm{C}$ warmer than reference period $1960-1991$, with $118.7 \mathrm{~mm}$ more rainfall than $2016 / 17$ and $95.2 \mathrm{~mm}$ more than 1960-1991. These obviously caused higher values for GL, GW, GT, GV and GA in 2015/16. However, as opposed to these traits, TGW and PC were lower.

Relationship between different grain characteristics were determined by a correlation. According to the results, there were no significant correlations between PC (\%) and remaining traits. This is in accordance with Varga et al. (2003), while in Abdipour et al. (2016), PC and GT correlated negatively and significantly at $\mathrm{P}<0.01\left(-0.256^{* *}\right)$. Five traits (GL, GW, GT, GV and GA) significantly correlated in our research, similar to Varga et al. (2003), Okamoto et al. (2013) and Yan et al. (2017).

Also, TGW positively and significantly correlated with GL, GW, GT, GV and GA as in Abdipour et al. (2016). In Varga et al. (2003) GL, GW and GT positively and significantly correlated with TGW. Also, TGW positively and significantly correlated with GL, GW and GA in Gegas et al. (2010) and Yan et al. (2017). Grain size and shape were positively correlated with TGW and they have affected wheat flour characteristics, yield and market price in Williams et al. (2013). Our results indicate that genotypes with larger grains obtained higher TGW.

\section{Conclusions}

Our results imply that genotypes Brkulja and Šiđanka bear some promising grain characteristics at the morphological level. Higher temperatures and precipitation increased grain width, thickness, volume and surface area, while thousand grain weight and grain protein content decreased at the same time. Also, genotypes Partizanka (12.88\%) and Vuka (12.38\%) obtained the highest protein content. Based on the protein content remaining genotypes can be categorized as genotypes with weak flour that can be used for the production of biscuits and cakes.

\section{References}

Abdipour M, Ebrahimi M, Izadi Darbandi A, Mastrangelo, AM, Najafian G, Arshad Y, Mirniyam G, 2016. Association between grain size and shape and quality traits, and path analysis of thousand grain weight in Iranian bread wheat landraces from different geographic regions. Not. Bot. Hortic. Agrobo. 44:228-36.

Cristina D, Ciuca M, Cornea PC, 2016. Genetic control of grain size and weight in wheat-where are we now? Sci. Bull. Ser. F. Biotechnol. 20:27-34.

Desheva G, 2014. Morphological and agronomical characterization of common wheat landraces (Triticum aestivum L.) from the National Wheat Collection of Bulgaria. Emir. J. Food Agr. 26:164-9

Dotlacil L, Hermuth J, Stehno Z, 2003. Earliness, spike productivity and protein content in European winter wheat landraces and obsolete cultivars. Plant Soil Environ. 49:67-74.

Dotlacil L, Hermuth J, Stehno Z, Dvoracek V, Bradová J and Leisova L, 2010. How can wheat landraces contribute to present breeding? Czech. J. Genet. Plant. 46:70-4.

Dziki D, Laskowski J, 2004. Influence of kernel size on grinding process of wheat at respective grinding stages. Pol. J. Food. Nutr. Sci. 13:29-33.

Gegas VC, Nazari A, Griffiths S, Simmonds J, Fish L, Orford S, Sayers, Doonan JH, Snapea JW, 2010. A genetic framework for grain size and shape variation in wheat. Plant Cell 22:1046-56.

Grabowski A, Siuda R, Lenc L, Grundas S, 2012. Evaluation of single-kernel density of scab-damaged winter wheat. Int. Agrophys. 26:129-35. 
Hasan AK, Herrera J, Lizana C, Calderini DF, 2011. Carpel weight, grain length and stabilized grain water content are physiological drivers of grain weight determination of wheat. Field Crops Res. 123:241-7.

Huebner FR, Bietz JA, Nelson T, Bains SG, Finney PL, 1999. Soft wheat quality as related to protein composition. Cereal Chem. 76:650-5.

Lizana, XC, Riegel R, Gomez LD, Herrera J, Isla A, McQueenMason SJ, Calderini DF, 2010. Expansions expression is associated with grain size dynamics in wheat (Triticum aestivum L.). J. Exp. Bot. 61:1147-57.

Nielsen JP, Pedersen DK, Munck L, 2003. Development of nondestructive screening methods for single kernel characterization of wheat. Cereal Chem. 80:274-80.

Okamoto Y, Nguyen AT, Yoshioka M, Iehisa JCM, Takumi S, 2013. Identification of quantitative trait loci controlling grain size and shape in the $\mathrm{D}$ genome of synthetic hexaploid wheat lines. Breed. Sci. 63:423-9.

Ortiz R, Trethowan R, Ortiz Ferrara G, Iwanaga M, Dodds JH, Crouch JH, Crossa J, Braun HJ, 2007. High yield potential, shuttle breeding and a new international wheat improvement strategy. Euphytica 157:365-84.

Oručević-Žuljević S, Džafić A, Akagić A, Spaho N, Vranac A, 2016. Relationship between selected quality parameters in spelt wheat grain. IJAIR 5:54-8.

Piergiovanni AR, 2013. Evaluation of genetic variation and grain quality of old bread wheat varieties introduced in north-western Italian environments. Genet. Resour. Crop Ev. 60:325-33.
Plessis A, Ravel C, Bordes J, Balfourier F, Martre P, 2013. Association study of wheat grain protein composition reveals that gliadin and glutenin composition are trans-regulated by different chromosome regions. J. Exp. Bot. 64:3627-44.

Punia S, Sandhu KS, Siroha AK, 2017. Difference in protein content of wheat (Triticum aestivum L.): effect on functional, pasting, colour and antioxidant properties. JSSAS 2:1-7.

Shewry PR, 2009. Wheat. J. Exp. Bot. 60:1537-53.

Varga B, Svečnjak Z, Jurković Z, Kovačević J, Jukić Ž, 2003. Wheat grain and flour quality as affected by cropping intensity, Food Technol. Biotech. 41:321-9.

Williams K, Munkvold J, Sorrells M, 2013. Comparison of digital image analysis using elliptic Fourier descriptors and major dimensions to phenotype seed shape in hexaploid wheat (Triticum aestivum L.). Euphytica, 190:99-116.

Xie, Q, Mayes S, Sparkes DL, 2015. Carpel size, grain filling, and morphology determine individual grain weight in wheat. J. Exp. Bot. 66:6715-30.

Yan L, Liang F, Xu H, Zhang X, Zhai H, Sun Q, Ni Z, 2017. Identification of QTL for Grain Size and Shape on the D genome of natural and synthetic allohexaploid wheats with near-identical AABB genomes. Front. Plant Sci. 8:1-14.

Zeven AC, 1999. The traditional inexplicable replacement of seed and seed ware of landraces and cultivars: a review. Euphytica 110:181-91.

Zou ZT, Yang WY, 1995. Development of wheat germplasm research in Sichuan province. Crop Genet. Resour. 2:19-20. 